\title{
INFLUENCE OF PLANT ASSOCIATIONS ON THE SILICON CYCLE IN THE SOIL-PLANT ECOSYSTEM
}

\author{
BOCHARNIKOVA, E.A. ${ }^{1}$ - MATICHENKOV, V.V. ${ }^{2 *}$ \\ ${ }^{1}$ Institute of Physical-Chemical and Biological Problems in Soil Science Russian Academy of \\ Sciences, Pushchino, Moscow region, 142292, Russia,E-mail: mswk@rambler.ru \\ ${ }^{2}$ Institute Basic Biological Problems Russian Academy of Sciences, Pushchino, Moscow region, \\ 142292, Russia \\ *Corresponding author \\ e-mail:Vvmatichenkov@rambler.ru \\ (Received $5^{\text {th }}$ February 2010; accepted 26 ${ }^{\text {th }}$ April 2012)
}

\begin{abstract}
Soluble Si compounds such as monosilicic and polysilicic acids affect chemicals and physical properties of the soil. The main aim of this study is to evaluate Si cycle in the various soil-plant systems via the determination of mobile $\mathrm{Si}$ forms in the soil and of the total content of $\mathrm{Si}$ in the plant associations. The concentrations of monosilicic acid, polysilicic acids and acid-extractable $\mathrm{Si}$ in unmowed meadow, mowed meadow, birch-aspen forest, spruce wood and agricultural land soil-plant systems, were tested at the soil depths of 0-10, 20-30 and 50-60 cm in a Russian region, south of Moscow. The annual content of $\mathrm{Si}$ within the investigated soil-plant systems was calculated. Forty to $80 \mathrm{~kg} \mathrm{ha}^{-1}$ of $\mathrm{Si}$ is annually removed from Grey Forest Soil (Luvisol). The concentration of monosilicic acid in the upper soil horizon depended on the type of plant association and on the total content of adsorbed Si. The removal of plant remains from the ecosystems resulted in decreased monosilicilic acid concentration in the upper soil horizon. The ecosystems which utilize annual plant remains increased the content of monosilicilic acid of the surface soil horizon. The concentration of monosilicic acid in the upper soil layer can be used as indicator of the stability of plant association. The unmowed meadow and the birch-aspen forest were characterized as ecosystems with accumulative type of Si cycle. The agricultural land, the mowed meadow and spruce wood all had alluvial type of Si cycle.
\end{abstract}

Keywords: monosilicilic acid, plant association, polysilicic acid, silicon cycle, soil-plant ecosystem

\section{Introduction}

Silicon ( $\mathrm{Si}$ ) is the second most abundant element of the earth surface. Numerous chemical, physical and biological soil processes are realized and controlled by this element (Matichenkov and Bocharnikova, 2001; Snyder et al., 2006). The content of Si usually ranges from $20-35 \%$ for clay or silt soils to $40-44 \%$ for sandy soils (Essington, 2003). Mainly, $\mathrm{Si}$ is present as quartz, alkaline earth and aluminum silicates, which forms a soil skeleton and these forms of Si are chemically or biochemically inert, but have influence on the soil physical properties (Conley 2002; Sommer et al., 2006). In the element mobility classification, $\mathrm{Si}$ is located in two positions as inert and as mobile element (Matichenkov et al., 2000). Mobile Si substances correspond to monosilicic acid, polysilicic acid, organo-silicon compounds and complex compounds with organic and inorganic substances (Matichenkov and Bocharnikova, 2001). These substances play a primary role in the global biogeochemical cycle of $\mathrm{Si}$ (Matichenkov and Bocharnikova, 1994; Wollast and McKenzie, 1983). Plant adsorbs Si in monosilicic acid or their anion forms (Epstein, 1999; Ma, 2003). The removal Si from the soil by plants can range from $20-40 \mathrm{~kg} / \mathrm{ha}$ for terrestrial ecosystems characterized by low level of biomass increasing up to $3000 \mathrm{~kg} / \mathrm{ha}$, which typifies the tropical and subtropical 
zones (Anderson, 1991; Wattean and Villemin, 2001). About 27.5 million tons of Si are adsorbed by plants and removed from cultivated areas annually (in comparison to Pabsoption, whose annual amount is of 18 million tons) (Bocharnikova and Matichenkov, 1994). Our calculations demonstrate that about 460 million tons of $\mathrm{Si}$ is annually involved in the global biological cycle, of which about 341 million tons of Si are in the continental ecosystems (Matichenkov and Bocharnikova, 1994). The intensification and volume of Si cycle in the terrestrial ecosystems can be compared with the cycle of such elements as phosphorus, potassium and calcium (Alexander et al., 1996; Exley, 1998; Lucas et al., 1993). However, the information about the terrestrial Si cycle and the effect of plant association relative to the forms and concentration of Si substances in the soil, are scanty and inadequate in order to better define the role and function of this element in the nature. Besides, to evaluate the biogeochemical Si cycle, only the total content of mobile Si is usually analyzed (Alexander et al., 1996; Bartoli, 1985; BasileDoelsch et al., 2005; Lucas et al., 1993). Whereas there are at least three forms of mobile Si which are present in the soil (Dietzel 2002; Iler, 1979; Matichenkov and Bocharnikova, 2001). These are: monosilicilic acid, polysilicic acid and organo-silicon compounds.

Monosilicilic acid is highly biochemical and geochemical active (Iler, 1979; Ma, 2003; Matichenkov et al., 2000). Monosilicilic acid can control the mobility of phosphates and can transform plant-unavailable $\mathrm{P}$ into plant-available by the replacement of $\mathrm{P}$ from $\mathrm{Ca}, \mathrm{Al}$ and $\mathrm{Mg}$ phosphates (Matichenkov and Ammosova, 1996). $\mathrm{Al}, \mathrm{Mg}$ and heavy metal toxicity may be also suppressed by monosilicic acid (Birchall, 1992; Bocharnikova et al., 1999). Monosilicilic acid has an effect on soil pH level (Iler, 1979). It controls the formation of secondary minerals and also the intensity of mineral weathering processes in the soil (Orlov, 1985; Olier, 1990; Horigushi, 1988). Monosilicic acid may be absorbed by plants and microorganisms (Epstein, 1999; Ma, 2003).

Monosilicilic acid is a product of Si containing minerals dissolution (Essington 2003; Iler, 1979). The solubility of minerals depends on the chemical structure and size of its particles. The highest solubility is inherent in amorphous silica with high surface area (Iler, 1979). In the surface soil horizons, amorphous silica is represented by biogenic silica forms (plant and microorganism phytoliths) and abiogenic substances formed as a result of precipitation and dehydration of soluble Si compounds (Clarke 2003; Bobrova, 1995; Summer et al., 2006). In plants and soil microorganisms, about $90 \%$ of adsorbed monosilicilic acid transforms into polymers or biogenic amorphous silica (Alexandre et al., 1996). Biogenic amorphous silica returns to the soil with plants or microbial remains and becomes a new source for monosilicilic acid (Sommer et al., 2006). By this means $\mathrm{Si}$ cycle is realized via monosilicic acid migration and transformation (Matichenkov and Bocharnikova, 1994). We suggested that monosilicilic acid plays a primary role in the terrestrial biogeochemical cycle of $\mathrm{Si}$ and provides for the movement of this element in the cycle itself (Matichenkov et al., 2000).

Polysilicic acid has two or more atoms of Si (Iler, 1979; Dietzel, 2002). Some molecules of polysilicic acid have thousands of $\mathrm{Si}$ atoms and can represent chains and branch of spherical forms of molecules (Chadwick et al., 1987 a; Chadwick et al., 1987 b). The term of "polysilicic acid" is under discussion now (Iler, 1979; Knight and Kinrade, 2001). It is recognized the following forms of polysilicic acid, as soluble silicic acid, which has more then 2 atoms of Si: oligomers (low molecular weight polysilicic acid), polysilicic acid (high molecular polysilicic acid, but without solid 
nucleus) and colloids, which according chemical classification must have solid nucleus and size from $10^{-7}$ to $10^{-5} \mathrm{~cm}$. Oligomers of silicic acids are characterized by high chemical activity (Dietzel, 2002; Knight and Kinrade, 2001). Our and literature data showed that this substances can be measured together with monosilicic acid, because during 10 minutes of interaction with molybdenum ammonium all monosilicic acid and most part of oligomers are formed colored compels (Dietzel, 2002; Matichenkov, 1990). The colloidal particles of polysilicic acid stir up solution, therefore we suggested to use centrifuge or fine filter for removing of these particles form other form of high molecular weight polysilicic acid (Matichenkov, 1990). It is necessary to recognize truth polysilicic acid and colloidal polysilicic acid because there are has different physical and chemical properties (Yazinin 1989, Matichenkov, 1990). Polysilicic acid has definite effect on soil adsorption capacity and soil structure (Yazinin, 1989; Matichenko et al., 1996). Polysilicic acid is chemically inert and is formed as the result of monosilicic acid polymerization (Iler, 1979; Matichenkov et al., 1996). Other ways of polysilicic acid formation were hypothesized but were not experimentally confirmed, for example, the direct formation from weathered minerals (Nazarov, 1976).

Plant associations and soil interplay and has great influence on each other (Alexandre et al., 1997; Bartoli, 1983; Basile-Doelsch et al., 2005). However the processes of interaction between single plant and plant association on the content and behaviors of $\mathrm{Si}$ are investigated poor. The understanding of the biogeochemical cycle of Si processes require more information about behavior of various forms of mobile $\mathrm{Si}$ in he soil-plant syetm.

We hypothesized that various plant associations absorb monosilicilic acid differentially and may control the concentration of monosilicilic acid and polysilicic acid in the upper soil horizons. As a result, a natural or anthropogenic change in plant association can modify $\mathrm{Si}$ cycle and influence soil mineral formation, weathering processes and some chemical and physical soil parameters.

The main aim of this study was to determine soil mobile Si substances in the five soil-plant systems, the total content of Si in plant association for boreal climatic zone and to evaluate the biogeochemical cycle of $\mathrm{Si}$.

\section{Materials and methods}

The selected ecosystems were located on the third terrace of the right side of riverbank of Oka River, south of Moscow region and $5 \mathrm{~km}$ west of Pushchino. This area was described as having identical quaternary period sediments, exposition and type of soil (Bazilevich,1993; Yermolaev and Shirshova,1994). The scheme of tested area is presented on Fig.1.

The unmowed and mowed meadows were used for long-term experiment, conducted by the Institute of Physical-Chemical and Biological Problems in Soil Science (Yermolaev and Shirshova, 1994). Sixteen years ago these areas were separated from plough land, which was used for agriculture over hundred of years. During this experiment, natural evolution of plant associations was examined by supporting meadows under unmowed and mowed technologies. Both plots were located on a slightly $\left(3-5^{\circ}\right)$ northern slope.

Plant from each plant association was described. The soil profiles for each plant association were prepared in third replication and type of each soil was determined. 


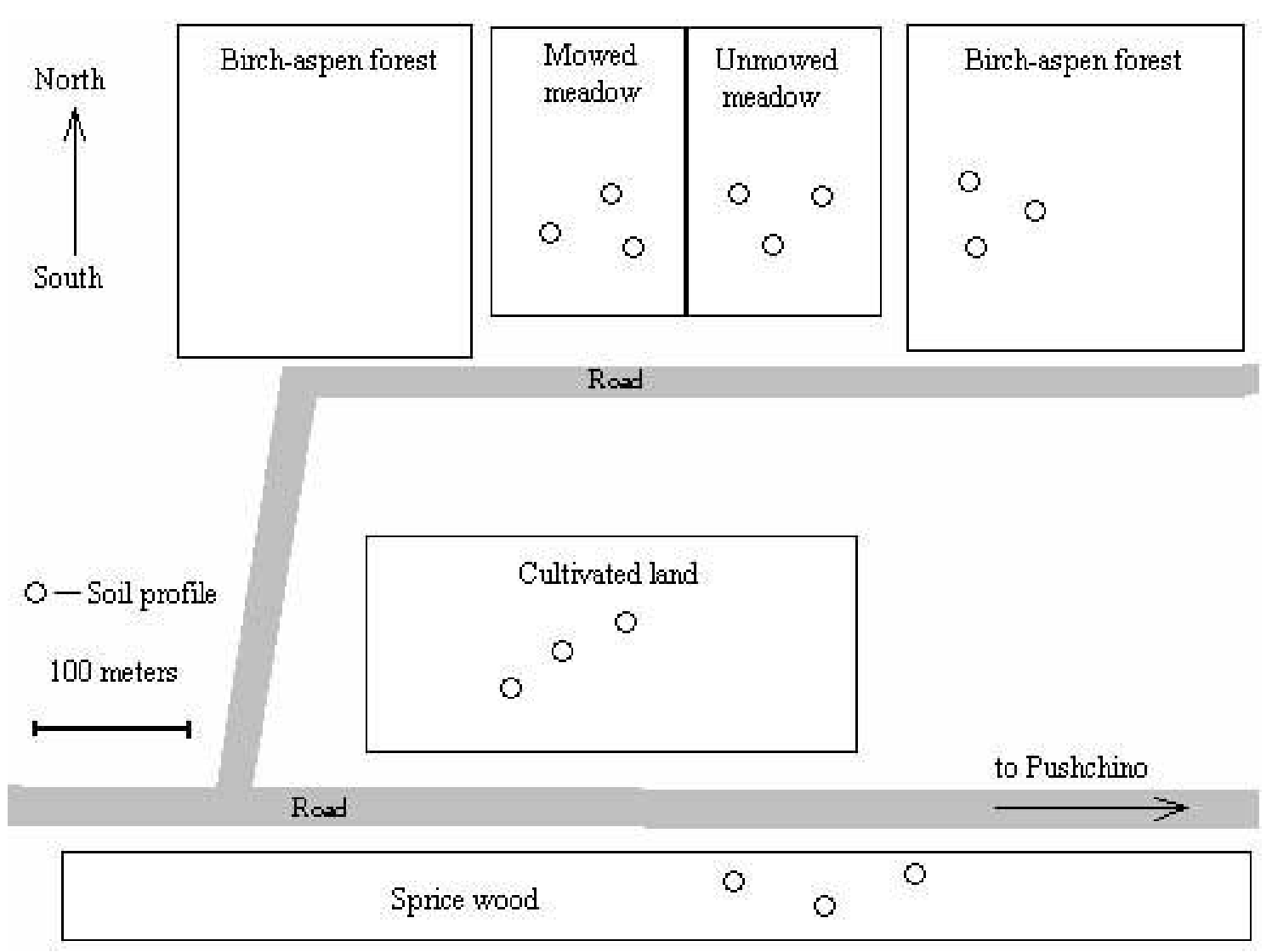

Figure 1. The scheme of the ecosystems and location of soil profiles

Grass and grass-rich herb phytocenosis were predominant in the meadow vegetation. The main components of the herbage were the following types: loose-tusock, and quitches grasses: Elytrigia repens L., Nevski, Bromopsis inermis Leyss. Holub., Dactylis glomerata L., Festuca pratensis Huds., Pod compressa L., Phleum pratense L., Anthoxanthum odoratum L., and Trifolium hybridum L., Trifolium pratense L.

Various cereals (Festuca pratensis Huds., Phleum pratense L., and Pod compressa L.) were characteristic of the unmowed meadow. Trifolium pratense L., Lathyrus pratensis $L$. and other non-cereals were typical of the mowed meadow.

Soil profiles of both meadows were identical. The soil was determined as Typical Grey Forest Soil (Russian Soil Classification) or Luvisol (FAO, 1991). Soil profile has the following description:

Horizon A (0-30 cm) was dark gray, with many average- and small-sized roots, damp clay-sand texture, courses of earthworms, clear boundary, and gradual transition to deeper horizon.

Horizon AB $(30-70 \mathrm{~cm})$ was brown with gray stains, small-sized roots, courses of earthworms, and damp clay-sand texture.

The ploughed land with barley (Hordeum vulgare) was located near the investigated meadows (200 $\mathrm{m}$ to the north-west). The soil was identical to the meadow soil, except the surface horizon $(0-30 \mathrm{~cm})$, which was formed by annual tillage. It didn't have roots and its color was more homogeneous. This field has been used in agriculture for over one hundred years (Yermolaev and Shirshova, 1994).

The next plant association was described in the forest. The secondary birch-aspen forest was located beside the mowed and unmowed meadows, on a slight northern slope 
(Figure 1). This area had the following plant composition and structure: the lime-bircthaspen wood - hazel, rich in grasses (Tilia cordata Mill. + Betula pendula Roth + Populus tremula L. - Corulus avellana L. - Lomicera Xylosteum L. Dum - Pulmoniaria obscura + Conval baria majlis $L$ - Fragaria vesca $L .+$ Veronica chamaedris L.). Plant samples in these points were collected separately for grasses, trees leafs and trees branches. The type of soil was classified as Light Grey Forest. The soil profile had the following structure:

Horizon A (0-12 cm) was gray, moist sand-clay with many large-, average-, and small-sized roots, and gradual transition to deeper horizon.

Horizon A2B $(12-30 \mathrm{~cm})$ was light gray with light brown stains, damp sand-clay texture, average and large roots, and gradual transition to deeper horizon.

Horizon AB $(30-70 \mathrm{~cm})$ was characterized by heterogeneous mixture of grays, browns and whites and damp sand-clay texture.

The final selected plant association was located in coniferous forest. The spruce wood was located on a hill with a few equal horizontal river platforms $(10-15 \mathrm{~m})$ alternated with southern slopes (5-10 $\mathrm{m}$ and 20-35 $)$ (Figure 1). It had the following plant composition and structure: Picea abies L. Karst $+\operatorname{single~Populus~tremula~} L$. without grass cover. Plant samples in these ecosystems were collected separately for needles and for branches of spruce. The type of soil was classified as Grey Forest with the following profile structure:

Organic litter $(0-3 \mathrm{~cm})$ represented damp and friable old needles and branches.

Horizon A1 (3-12 cm) was dark gray, with few large roots, damp clay-sand texture, unclear boundary and gradual transition to deeper horizon.

Horizon A2B $(12-40 \mathrm{~cm})$ was characterized by heterogeneous light gray color with brown stains, damp clay-sand texture, unclear boundary and gradual transition to deeper horizon.

Horizon $\mathrm{AB}(40-80 \mathrm{~cm})$ was similar to horizon $\mathrm{A} 2 \mathrm{~B}$, brown without light gray material.

Soil and plant samples were pick out from each described ecosystems. Double soil samples were collected form each soil profile at the depth of 0 to $10 \mathrm{~cm}, 20$ to $30 \mathrm{~cm}$ and 50-60 cm. The mixed plant samples (total herb cutting from $25 \times 25 \mathrm{~cm}$ area) were collected from each point of soil sample, with three replications. Plant samples were measured and dried at $65^{\circ} \mathrm{C}$. Then plant samples were grounded and then passed through a $0.5-\mathrm{mm}$ sieve. Total Si was tested by Eliot and Snyder (1991) method with four replications for each sample. Samples of plant tissue weighing $100 \mathrm{mg}$ were wetted with $2 \mathrm{~mL}$ of $50 \% \mathrm{H}_{2} \mathrm{O}_{2}$ in $100-\mathrm{mL}$ polyethylene tubes. To each tube was added $4.5 \mathrm{~g}$ of $50 \% \mathrm{NaOH}$ at ambient temperature, and each tube was gently vortexes. The tubes were individually covered with lose-fitting plastic caps. The rack of tubes was placed in an autoclave at $138 \mathrm{kPa}$ for $1 \mathrm{~h}$. After atmospheric pressure was reached, the tubes were removed and the contents brought to $50 \mathrm{~mL}$ with distilled water (Eliot and Snyder, 1991). Monosilicilic acid in final solution form tubes was determined colorimetrically (Mallen and Raily method cited by Iler, 1979). The average content of total Si was calculated for each point.

Each fresh soil sample was divided into 2 sub-samples. One-half of the sub-samples was air-dried and grounded to pass a 1-mm sieve. These dried soil samples were tested for biogeochemically active amorphous silica (Matichenkov et al., 1997). The remaining sub-samples were maintained under fresh condition after removing roots and passing through a 2-mm sieve. Monosilicilic acid was determined in water extracted 
from fresh soil samples (Mallen and Raily method cited by Iler, 1979). The extraction procedure was conducted in the following manner: $6 \mathrm{~g}$ of fresh soil were placed into beakers. Thirty $\mathrm{mL}$ of distilled water were added to each beaker. After 1-hour shaking, the sample was filtered through filter paper No.40, then the extract was analyzed for monosilicilic acid. Polysilicic acid was analyzed in the same extract after depolymerization. For depolymerization, an aliquot $(20-25 \mathrm{~mL})$ was subjected to ultrasound for $1 \mathrm{~min}$. During this time, all of polysilicic acid was transformed into monosilicic acid (Matichenkov et al., 1997). It should be noted from our earlier work that a change in soil moisture from 50 to $500 \mathrm{~g} \mathrm{~kg}^{-1}$ has no effect on the sensitivity of this method (Matichenkov et al. 1997; Matichenkov and Snyder, 1996).

Biochemically active amorphous Si was tested in dry soil samples after a 1day acid extraction procedure $(20 \mathrm{~mL} 0.1 \mathrm{M} \mathrm{HCl}$ from air-dried, 2-g sample) (Barsykova and Rochev, 1979). The extract was filtered through filter paper No.40 and analyzed for Si content using the colorimetric method (Mallen and Raily method cited by Iler, 1979). The concentration of $\mathrm{Si}$ was determined photo metrically at $660 \mathrm{~nm}$. $\mathrm{pH}$ level and moisture of tested soils was determined by standard methods (Thomas,1996).

All obtained data was subjected to a statistical analysis based on comparative methods using Duncan's multiple range tests for mean separation at the 5\% level of significance (Duncan, 1955).

The literary data on biomass productivity of tested ecosystems was used for the calculation of $\mathrm{Si}$ including the biological cycle (Yermolaev and Shirshova, 1979; Bazilevich, 1993). Only above-ground biomass was used for these calculations.

\section{Results}

The maximum amount of monosilicilic acid in the surface horizons was observed for unmowed meadow (17.7 $\mathrm{mg} \mathrm{Si} \mathrm{kg}^{-1}$ ) and birch-aspen forest (16.2 $\mathrm{mg} \mathrm{Si} \mathrm{kg}^{-1}$ ) (Table 1). Lower concentrations of monosilicic acid in the surface horizons were tested for cultivated soil $\left(6.5 \mathrm{mg} \mathrm{Si} \mathrm{kg}^{-1}\right)$, the mowed meadow soil $\left(8.6 \mathrm{mg} \mathrm{Si} \mathrm{kg}^{-1}\right)$ and the spruce wood soil $\left(9.9 \mathrm{mg} \mathrm{Si} \mathrm{kg}^{-1}\right)$. It is necessary to note that concentrations of monosilicilic acid in the soil surface horizons of all investigated ecosystems were significantly different. With depth, the concentration of monosilicilic acid tended to increase, ranging from 10.2 to $15.6 \mathrm{mg} \mathrm{Si} \mathrm{kg}^{-1}$.

The cultivated soil was characterized by the highest concentration of polysilicic acid: $25 \mathrm{mg} \mathrm{Si} \mathrm{kg}{ }^{-1}$. The soils of both meadows at the depth of $20-30 \mathrm{~cm}$ were also characterized by high concentration of polysilicic acid (26.2-30.3 mg Si kg-1) (Table 1). Both forest soils had the lowest concentration of polysilicic acid, except the subsurface horizon under birch-aspen forest. In the rest soil horizons of the forest ecosystems, the polysilicic acid concentration ranged from 1.8 to $9.6 \mathrm{mg} \mathrm{Si} \mathrm{kg}^{-1}$.

The difference in amorphous silica concentration in the investigated soils wasn't as high as that in silicic acids (Table 1). The maximum concentration of amorphous silica was determined in the deeper horizons. Its value in the lower horizons for forest ecosystem and moved meadow were not significantly different (Table 1). The unmowed meadow soil and cultivated soil exhibited the maximum concentration of amorphous silica in the surface soil horizons (527 and $500 \mathrm{mg} \mathrm{Si} \mathrm{kg}^{-1}$, respectively) (Table 1). 
Table 1. Concentration of soil Si compounds ( $m g \mathrm{Si} \mathrm{kg}^{-1}$ )

\begin{tabular}{|c|c|c|c|c|c|}
\hline Samples & $\mathbf{p H}$ & $\mathbf{W} \%$ & Monosilicic acid & Polysilicic acid & $\begin{array}{c}\text { Acid-extractable } \\
\text { Si } \\
\end{array}$ \\
\hline & & & \multicolumn{3}{|c|}{ 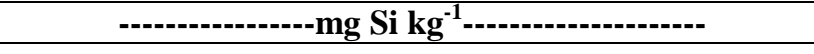 } \\
\hline \multicolumn{6}{|l|}{ Mowed meadow } \\
\hline $0-10 \mathrm{~cm}$ & 5.87 & 19.4 & $8.6 \mathbf{i}$ & $18.9 d$ & $415 \mathrm{~cd}$ \\
\hline $20-30 \mathrm{~cm}$ & 5.66 & 14.6 & $10.8 \mathrm{~g}$ & $26.2 \mathbf{b}$ & $455 \mathrm{c}$ \\
\hline $50-60 \mathrm{~cm}$ & 6.01 & 13.2 & $12.1 \mathrm{e}$ & $7.8 \mathbf{h}$ & $537 \mathbf{b}$ \\
\hline \multicolumn{6}{|c|}{ UNMOWED MEADOW } \\
\hline $0-10 \mathrm{~cm}$ & 6.24 & 20.8 & $17.7 \mathbf{a}$ & $15.8 \mathbf{e}$ & $527 \mathbf{b}$ \\
\hline $20-30 \mathrm{~cm}$ & 6.05 & 14.5 & $10.2 \mathrm{gh}$ & $30.3 \mathbf{a}$ & $468 \mathbf{c}$ \\
\hline $50-60 \mathrm{~cm}$ & 6.01 & 13.2 & $13.1 \mathrm{e}$ & $7.5 \mathbf{h}$ & $548 \mathbf{b}$ \\
\hline \multicolumn{6}{|c|}{ AGRICULTURAL LAND } \\
\hline $0-10 \mathrm{~cm}$ & 6.28 & 13.0 & $6.5 \mathbf{j}$ & $25.0 \mathrm{c}$ & 500 bc \\
\hline $20-30 \mathrm{~cm}$ & 6.14 & 13.0 & $6.5 \mathbf{j}$ & $25.0 \mathrm{c}$ & $510 b$ \\
\hline $50-60 \mathrm{~cm}$ & 6.06 & 17.6 & $13.9 \mathrm{~d}$ & $12.7 \mathbf{f}$ & $592 \mathbf{a}$ \\
\hline
\end{tabular}

Birch-aspen forest

\begin{tabular}{rrrccc}
\hline $0-10 \mathrm{~cm}$ & 6.22 & 13.4 & $16.2 \mathbf{b}$ & $4.1 \mathbf{i}$ & $382 \mathbf{d}$ \\
\hline $20-30 \mathrm{~cm}$ & 5.12 & 12.3 & $11.5 \mathbf{f}$ & $18.6 \mathbf{d}$ & $428 \mathbf{c}$ \\
\hline $50-60 \mathrm{~cm}$ & 5.47 & 12.9 & $15.3 \mathbf{c}$ & $1.8 \mathbf{j}$ & $532 \mathbf{b}$ \\
\hline
\end{tabular}

Spruce wood

\begin{tabular}{rrrccc}
\hline $0-10 \mathrm{~cm}$ & 4.76 & 25.6 & $9.9 \mathbf{h}$ & $8.1 \mathbf{h}$ & $432 \mathbf{c}$ \\
\hline $20-30 \mathrm{~cm}$ & 5.87 & 13.7 & $14.4 \mathbf{d}$ & $1.8 \mathbf{j}$ & $539 \mathbf{b}$ \\
\hline $50-60 \mathrm{~cm}$ & 6.16 & 10.8 & $15.6 \mathbf{c}$ & $9.6 \mathbf{g}$ & $534 \mathbf{b}$ \\
\hline
\end{tabular}

$\dagger$ Value within a column followed by the same letter are not different using Duncan's Multiple Range test $(\mathrm{P}<0.05)$.

The total content of $\mathrm{Si}$ in plant association is presented in Table 2. The highest concentration of Si (1.75\% from dry mass) was observed in the spruce needles. This data correspond with Bazilevic's content of Si in the needles of Picea abies, which was determined in same region (1993). It is necessary to note that content of Si in the spruce needles from mountain region area are lover (Carnelli et al., 2001), which can be explain by difference in the mobile Si content in the soils.

The plant association in the unmowed meadow and barley collected from cultivated area was also characterized by high content of Si in green mass of plants (Table 2). This content of $\mathrm{Si}$ is typical for cereals (Ma, 2003). Then ext level of total Si in plant association was $1.15 \%$ and this level was determined in grass cover of birch-aspen forest. The content of total $\mathrm{Si}$ which was determined for plants from mowed meadow and leafs from birch and aspen trees fluctuate around $1.03-1.06 \%$ of Si (Table 2). The lowest concentrations of $\mathrm{Si}$ in plants were determined in the trees branches. It is important to note that the content of $\mathrm{Si}$ in the spruce wood was three times higher then in birch or aspen trees (Table 2).

The obtained and literature data allowed us to calculate the balance of Si in the tested plant associations (Table 3). The calculated data of Si pool in the ecosystem biomass has demonstrated that the maximum Si $\left(87.6 \mathrm{~kg} \mathrm{Si} \mathrm{ha}^{-1}\right)$ was present in the spruce wood biomass (Table 3). About half of the plant adsorbed Si was concentrated in the wood. Trees were accumulating this Si during 30-40 years. The annual Si absorption by spruce 
was only $40.2 \mathrm{~kg} \mathrm{Si} \mathrm{ha}{ }^{-1}$ plus about $2-4 \mathrm{~kg} \mathrm{Si} \mathrm{ha}^{-1}$ accumulated in the wood. Consequently, we can suggest that the most active annual Si uptake by plants occurs in the unmowed meadow and agricultural ecosystem $\left(79.1\right.$ and $81.5 \mathrm{~kg} \mathrm{Si} \mathrm{ha}{ }^{-1}$, respectively) (Table 3). The lowest $\mathrm{Si}$ absorption was calculated for the birch-aspen forest.

Table 2. The total content of Si in the tested plant associations

\begin{tabular}{l|c}
\hline \multicolumn{1}{c|}{ Area } & Total Si, \% from dry mass \\
\hline Unmowed meadow & $1.49 \mathbf{b}$ \\
Mowed meadow & $1.03 \mathbf{d}$ \\
Cultivated land & $1.34 \mathbf{b}$ \\
Birch-aspen forest & \\
$\quad$ grass & $1.15 \mathbf{c}$ \\
$\quad$ trees leafs & $1.06 \mathbf{d}$ \\
$\quad$ trees branches & $0.36 \mathbf{e}$ \\
Spruce wood & \\
$\quad$ needles & $1.75 \mathbf{a}$ \\
$\quad$ branches & $0.97 \mathbf{d}$ \\
\hline
\end{tabular}

$\dagger$ Value within a column followed by the same letter are not different using Duncan's Multiple Range test $(\mathrm{P}<0.05)$.

The amount of annually returned biomass into the soil is important in order to calculate Si balance in an ecosystem (Bazilevich,1993). The removal of plant biomass as crops from cultivated land and meadow cutting, is approximated $95 \%$ of aboveground vegetable mass. In wood ecosystems, some $\mathrm{Si}$ absorbed is found in the wood mass (50\% in birch-aspen forest and 54\% in spruce woods) (Table 3). Probably all this Si will not return into the soil because local forest district moves out wood material. Only in the unmowed meadow soil-plant system, all of the absorbed Si returns into the soil (Table 3).

Table 3. The biological Si cycle in various soil-plant systems

\begin{tabular}{|c|c|c|c|c|c|}
\hline Area & $\begin{array}{c}\text { Annual } \\
\text { increase in } \\
\text { biomass } \\
\text { t/ha/year }\end{array}$ & $\begin{array}{c}\text { Annual } \\
\text { returning plant } \\
\text { debris into soil, } \\
\%\end{array}$ & $\begin{array}{c}\text { Annual removal } \\
\text { of Si from soil, } \\
\qquad \mathbf{k g ~ S i ~ h a}{ }^{-1}\end{array}$ & $\begin{array}{c}\text { Annual return of } \\
\mathrm{Si} \text { into soil, } \\
\mathrm{kg} \mathrm{Si} \mathrm{ha}^{-1}\end{array}$ & Balance of $\mathrm{Si}$ \\
\hline $\begin{array}{l}\text { Unmowed } \\
\text { meadow }\end{array}$ & 5.21 & 100 & 78.09 & 78.09 & 0 \\
\hline Mowed meadow & 5.98 & 5 & 61.14 & 3.07 & -58.07 \\
\hline $\begin{array}{l}\text { Cultivated land } \\
\text { Birch-aspen } \\
\text { forest }\end{array}$ & 6.10 & 5 & 81.50 & 4.07 & -77.43 \\
\hline $\begin{array}{r}\text { green mass } \\
\text { wood }\end{array}$ & $\begin{array}{c}2.5 \\
4.72\end{array}$ & $\begin{array}{c}50 \\
0\end{array}$ & $\begin{array}{c}27.75 \\
16.99 \\
\text { sum }-44.74\end{array}$ & 27.75 & -16.99 \\
\hline $\begin{array}{r}\text { Spruce wood } \\
\text { green mass } \\
\text { wood }\end{array}$ & $\begin{array}{c}2.3 \\
4.99\end{array}$ & $\begin{array}{c}46 \\
0\end{array}$ & $\begin{array}{c}40.25 \\
47.40 \\
\text { sum }-87.65\end{array}$ & $40.35^{*}$ & $\begin{array}{c}-47.40^{*} \\
\text { sum }-87.65^{*}\end{array}$ \\
\hline
\end{tabular}

* Needles fallen don't mix with soil forming surface layer $(0-3 \mathrm{~cm})$. 


\section{Discussion}

Primary and secondary soil minerals are the principal sources of soluble Si forms. Soil Si-rich minerals differs in solubility and are influenced by numerous factors such as $\mathrm{pH}$, particle size, chemical composition, climate, plants, soil microorganisms activity et al. (Lucas et al., 1993). It is possible to distinguish 3 main directions of Si migration and transformation in the soil: leaching of soluble Si-rich compounds without transformation, adsorption of monosilicilic acid by plant roots with consequent transformation of monosilicic acid into amorphous silica, and transformation of soluble forms of Si into the soil without movement from the soil profile. The pool of Si leached depends on the amount of atmospheric precipitates and velocity of weathering (Matichenkov et al., 2000). Polysilicilic acids are more leacheable, then monosilicic acid, and this is due to the peculiar chemical structure of these substances. (Matichenkov et al., 1996). Monosilicic acid has a positive charged anion which is absorbed very well by the soil particles, while the non-compensated electrical charge of polysilicic acid can be self- neutralized by the high flexibility of polysilicic acid molecule (Iler, 1979). Plant roots and soil microorganisms produce organic acids that accelerate mineral weathering (Alexandre, et al., 1996; Drever, 1993).

Higher plants are responsible for the absorption of $\mathrm{Si}$ via monosilicic acid through the soil profile. In plant tissues, Si precipitates as phytoliths in cell walls or filling of the cell lumen and in the intercellular spaces (Alexandre et al., 1996). Soil microorganisms adsorb monosilicic acid and then transform it into polysilicic acid and amorphous Si. When plant or soil microorganism die, the adsorbed and transformed Si returns to the soil. The distribution of phytoliths through the soil profile is conditioned by two different mechanisms: translocation into lower horizons and accumulation in upper soil horizon (Bobrova, 1995).

This means that soil minerals, climate conditions, and living organisms are the prime factors that determine Si movement and transformation also known as Si cycle of the soil-plant ecosystem. There are two main $\mathrm{Si}$ cycles in nature: cumulative and eluvial (Matichenkov et al. 2000). The accumulative Si cycle is characterized by soils with accumulation of Si substances in the upper soil layer. Ecosystems with accumulative Si cycles, phytolith formation dominates over leaching Si-rich substances. The steppe ecosystems are an example of this type of Si cycle. The content of phytoliths in such soil may range from $6 \%$ to $12 \%$ of mass in surface horizon (Bobrova, 1995).

The eluvial $\mathrm{Si}$ cycle is characteristic of soils having high levels of physical and chemical weathering besides intensive Si leaching, caused by climatic conditions. Plant activity, in these kinds of ecosystems characterized by this type of Si cycle, may be very high but absorbed Si doesn't accumulate in the soil. For example, tropical rain forests often have the eluvial $\mathrm{Si}$ cycle where about $90 \%$ of biologically active $\mathrm{Si}$ of this ecosystem is found in the biomass, not in the soil (Matichenkov and Bocharnikova 1994). Eighty to $90 \%$ of total $\mathrm{SiO}_{2}$ can be removed from the soil profile in humid tropic zones (Kovda, 1985).

In our study, all examined soil-plant systems were located on similar parent material and formed under equal climatic conditions. Only plant associations were different. As a result the role of plant association in these tested ecosystems had critical significance due to the distinction of Si cycles.

It is obvious that monosilicic acid concentration in the soil depends on the type of plants and the amount of vegetative biomass removed from the ecosystem. Returning biomass in unmowed meadow and birch-spruce forest was responsible for increasing 
monosilicic acid in the surface horizon of these ecosystems (Table 1). It is interesting that a negative Si balance in birch-spruce forest emerged at the depth of $20-30 \mathrm{~cm}$ (Table 1). This layer was supplied with tree roots.

The increased concentration of monosilicic acid in unmowed meadow soil is the result of the transformation of Si containing minerals into the following mechanism. A parent material was the primary source of monosilicic acid. First plants absorbed Si and formed phytholites (Table 2). Than plant remains, with formed phytoliths, returns into soil. Phytoliths represent fine amorphous silica whose solubility is usually higher than that of most soil minerals (Iler, 1979). This process repeated annually increased, over time, the content of phytholites in soil and consequently the concentration of monosilicic acid also increased (Table 1).

In spruce wood, absorbed silica is accumulated mainly in the needles (Table 2). Fallen needles form a compact surface layer and this layer does not mix with the soil. The decomposition of spruce needles is a long-term process (Bazilevich, 1993). In the upper soil horizon of spruce wood, only small amount of monosilicic acids was observed (Table 1).

The cultivated soil and mowed meadow soil were characterized by smaller concentration of monosilicic acids in the upper horizons because in both ecosystems absorbed $\mathrm{Si}$ is harvested with the crop and doesn't return to the soil (Tables 1, 2 and 3). It is important to notice that this situation has a negative effect on plant growth. A deficiency in Si nutrition leads to decreasing cereals viability and resistance to diseases and insect attacks (Datnoff et al., 1997; Snyder et al., 2006). Cereal growth decreases when Si nutrition is very small (Bocharnikova, 1996; Matichenkov, 1990). Probably, this explains why Si deficiency was responsible for a change in plant association on the mowed meadow where wild Si-rich cereals were displaced by other plants (Lathyrus pratensis L., Trifolium pratence L.) (Yermolaev and Shirshova, 1994).

The increases content of polysilicic acid in plough soil was probably due to mechanical compaction of agricultural equipment. These results correlate very well with our previous data regarding Chermozem soil (Matichenkov et al., 1996). Machine pressure may increase polysilicic acid in the upper soil horizons, however the chemistry of these processes has been poorly investigated.

The soil at the depth of 20-30 $\mathrm{cm}$ in both meadow ecosystems contained high amount of polysilicic acid as well (Table 1). This is probably caused by the same reason as in arable areas, where the land was used as tillage 16 years ago and polysilicic acid might have been retained (Yermolaev and Shirchova,1994).

The concentrations of acid-extractable $\mathrm{Si}$ were similar in the upper horizons of all tested soils besides the unmowed meadow and plough land (Table 1). This increasing of acid-extractable $\mathrm{Si}$ can be ascribed to the acceleration of the weathering process in the cultivated soil and to a significant amount of plant phytholites in the unmowed meadow soil (Bobrova, 1995; Kovda, 1985). Both processes have identical data on chemical testing (Barsukova and Rochin, 1979; Matichenkov et al., 1997; Matichenkov et al., 2000). The monosilicic acid concentration in both ecosystems may serve as an indicator for the direction of mineral transformation processes that are: the accumulation of phytoliths for the unmowed meadow (high level of monosilicic acid) and the acceleration of weathering for the cultivated soil (low level of monosilicic acid).

The correlating coefficients between different Si forms in the soil (Table 1) and the balance of elements in the soil-plant systems (Table 3) were calculated. A linear dependence of the type $\mathrm{Y}=\mathrm{AX}+\mathrm{B}$ was used. 
Calculations have demonstrated that a high correlation exists between the concentration of monosilicic acid in the soil and the balance of $\mathrm{Si}$ in the ecosystem: $\mathrm{r}=0.98, \mathrm{p}=0.001, \mathrm{sd}=0.759$. The relationship between other examined forms of $\mathrm{Si}$ in soil and the balance of $\mathrm{Si}$ in the ecosystem had no significant level:

$\mathrm{r}=0.0313, \mathrm{p}=0.96, \mathrm{sd}=10.82$ for sum of soluble $\mathrm{Si}$ forms,

$\mathrm{r}=-0.75, \mathrm{p}=0.26, \mathrm{sd}=7.29$ for polysilicic acid, and

$\mathrm{r}=0.100, \mathrm{p}=0.87, \mathrm{sd}=73$ for acid-extractable Si.

These calculations showed that monosilicic acid concentration in the upper soil horizon strongly depends on the type of plant association when compared with ecosystems having similar type of soil. Monosilicic acid represents the main component in the biogeochemical $\mathrm{Si}$ cycle of the soil-plant ecosystem (Matichenkov, Bocharnikova,1994; Nazarov,1976). Monosilicic acid also controls many soil properties and has a direct effect on plants and microorganism growth. In turn, plants (type of plant cover) can control the monosilicic acid concentration in the upper soil horizons as well. As a result, we are dealing with a complicated and self-regulating $\mathrm{Si}$ biogeochemical cycle in the soil-plant ecosystem.

The unmowed meadow and birch-aspen forest plant associations are responsible for increasing the concentration of monosilicic acid in the upper soil layer which optimizes plant Si nutrition. Silicon-accumulative plants (grasses) have competition priority. Both ecosystems are characterized by accumulative type of $\mathrm{Si}$ cycle. The removal of $\mathrm{Si}$ as a result of agricultural activity, grazing or accumulation of $\mathrm{Si}$ in unavailable forms (spruce wood) can change Si cycle and cause conversion changes for the soil-plant system: degradation of soil minerals, replacement of plant population where non $\mathrm{Si}$ accumulative plants have competitive priority. By this means that agriculture land, mowed meadow and spruce wood have typical eluvial Si cycle.

\section{Conclusion}

This investigation clearly shows that the biological cycle of $\mathrm{Si}$ is characterized by 40 to $80 \mathrm{~kg} \mathrm{Si} \mathrm{ha}{ }^{-1}$ annually removed from Grey Forest Soil. The monosilicic acid concentration in the upper soil horizons strongly depends on the type of plant association. The removal of plant biomass from the ecosystem results in decreasing monosilicic acid concentration in the upper soil horizons. Si movement from lower soil horizons to surface layer can occur via the adsorption of monosilicic acid by plants and by returning phytoliths into the soil. The concentration of monosilicic acid in the upper soil layer may serve as an indicator of straining in the Si biological cycle, stability of existing plant association and direction of the ecosystem evolution. The unmowed meadow and the birch-aspen forest were characterized as ecosystems with accumulative type of Si cycle. The agricultural land, the mowed meadow and spruce wood are all eluvial type Si cycle.

Acknowledgements. The authors are grateful to Dr. Yermolaev, A.M. and Mr. Murgo, F.F. for assistance. 


\section{REFERENCES}

[1] Aleshin, N.E., Avakian, A.P., Aleshin, E.P. (1990): The content of Si in DNA of rice. Reports of UAAS 6: 12-13.

[2] Alexandre, A., Meunier, J.D., Colin, F., Koud, J.M. (1997): Plant impact on the biogeochemical cycle of $\mathrm{Si}$ and related weathering processes. - Geochem et Cosmo Chem. Acta 61: 677-682.

[3] Anderson, D.L. (1991): Soil and leaf nutrient interactions following application of calcium silicate slag to sugarcane. - Fertilizer Research 30: 9-18.

[4] Barsykova, A.G., Rochev, V.A. (1979): Influence of silico-gel-rich fertilizers on mobile silicic acids in soil and on its availability for plants. - In: Control and Management of the Content of Macro- and Microelements in the Middle Ural Region. Proceedings of Sverdlovsky ACI 54: 84-88.

[5] Bartoli, F. (1983): The biogeochemical cycle of Si in two temperature forest ecosystems. Environ. Biogeochem. - Ecol. Bull. 35: 469-476.

[6] Basile-Doelsch, I., Meunier, J.D., Parron, C. (2005): Another continental pool in the terrestrial silicon cycle. - Nature 433: 399-402.

[7] Bazilevich, N.I. (1993): Biological Productivity of North Eurasian Ecosystems. - Nayka, Moscow.

[8] Bendz, G., Linqvist, I. (eds.) (1977): Biochemistry of Si and related problem. - In: $40^{\text {th }}$ Nobel Symposium, Plenum Press, New York.

[9] Bobrova, E.K. (1995): Biogenic Silica in Complex Genesis Soils. - Author ef. can.diss. Moscow State University, Moscow.

[10] Bocharnikova, E.A. (1996): The study of direct silicon effect on root demographics of some cereals. - In: Root Demographics and Their Efficiencies in Sustainable Agriculture, Grasslands, and Forest Ecosystems, Fifth Symp. Int. Soc. of Root Research July 14-18 1996. pp. 106 Madrea Conference Conter-Clenson, South Carolina.

[11] Bocharnikova, E.A., Matichenkov, V.V., Snyder, G.H. (1999): The management of Heavy metal behavior and mobility in the soil-plant system. - In: $31^{\text {th }}$ Mid-Atlantic Industrial and Hazardous Waste Conference, June 1999, 614-622.

[12] Carnelli, A.L., Madella, M., Theurillat, J.P. (2001): Biogenic silica in selected alpine plant species and plant communities. - Annals of Botany 87: 425-434.

[13] Chadwick, O.A., Hendricks, D.M., Nettleton, W.D. (1987a): Silica in duric soils: I A depositional model. - Soil Sci. Soc. Am. J. 51: 975-982.

[14] Chadwick, O.A., Hendricks, D.M., Nettleton, W.D. (1987b): Silica in duric soils: II Mineralogy. - Soil Sci. Soc. Am. J. 51: 982-985.

[15] Clarke, J. (2003): The occurrence and significance of biogenic opal in the regolith. Earth Sci. Rev. 60: 175-194.

[16] Conley, D.J. (2002): Terrestrial ecosystems and the global biogeochemical silica cycle. Global Biogeoch. Cycl. 16: 1121-1129.

[17] Datnoff, L.E., Snyder, G.H., Deren, C.W. (1997): Silicon fertilization for disease management of rice in Florida. - Crop Protec. 16: 525-531.

[18] Dietzel, M. (2002): Interaction of polysilicic and monosilicic acid with mineral surfaces. - In: Stober, I., Bucher, K. (eds.) Water-rock interaction. Kluwer, Netherlands, pp. 207235.

[19] Duncan, D.B. (1955): Multiple range and multiple F test. - Biometrics 11: 1-42.

[20] Essington, M.E. (2003): Soil and water chemistry. An integrative approach. - CRC Press London. pp.552.

[21] Exley, C. (1998): Silicon in life: A bioinorganic solution to bioorganic essentiality. Inorg. Biochem. 69: 139-144.

[22] Elliot, C.L., Snyder, G.H. (1991): Autoclave-induced digestion for the colorimetric determination of silicon in rice straw. - J. Agric. Food Chem. 39: 1118-1119.

[23] Epstein, E. (1999): Silicon. - Annu. Rev. Plant Physiol. Plant Mol. Biol. 50: 641-664. 
[24] FAO (1994): World Reference Base for Soil Resources. - Wageningen, Rome.

[25] Horigushi, T. (1988): Mechanism of manganese toxicity and tolerance of plant. IV. Effect of silicon on alleviation of manganese toxicity of rice plants. - Soil Sci. Plant Nutr 34: 65-73.

[26] Iler, R.K. (1979): The Chemistry of Silica. - Wiley, New York.

[27] Knight, C.T.G., Kinrade, S.D. (2001): A primer on the aqueous chemistry of silicon. - In: Silicon in Agriculture. Datnoff, L.E., Snyder, G.H., Korndorfer, G.H., (Eds) Elsevier, Amsterdam, 57-84.

[28] Kovda, V.A. (1985): Biogeochemistry of Soil Cover. - Nayka, Moscow.

[29] Lindsay, W.L. (1979): Chemical Equilibria in Soil. - John Wiley \& Sons, New York.

[30] Lucas, Y., Luizao, F.J., Chauvel, A., Rouiller, J., Nahon, D. (1993): The relation between biological activity of the rain forest and mineral composition of soil. - Science 260: 521523.

[31] Ma, J.F. (2003): Functions of silicon in higher plants. - In: Müller, W.E.G. (ed.) Silicon biomineralization. Springer Verlag, Berlin, pp. 127-148.

[32] Matichenkov, V.V. (1990): Amorphous oxide of silicon in soddy podzolic soil and its influence on plants. - Authoref. can. diss. Moscow State University. Moscow.

[33] Matichenkov, V.V., Ammosova, Y.M. (1996): Effect of amorphous silica on soil properties of sod-podzolic soil. - Eurasian Soil Science 28: 87-99.

[34] Matichenkov, V.V., Bocharnikova, E.A. (1994): Total and partial biogeochemical cycle of $\mathrm{Si}$ in various ecosystems. - In: Monge-Najera, J. (ed.) Sustainable Development: the View from the Less Industrialized Countries, UNED, San Jose, Costa Rica, 467-481.

[35] Matichenkov, V.V., Bocharnikova, E.A., Ammosova, J.M. (1997): The method for determination of plant available silica in soil. - Agrochemistry 1: 76-84.

[36] Matichenkov, V.V., Pinsky, D.L., Bocharnikova, E.A. (1996): Influence of mechanical compaction of soils on the state and forms of available Si. - Eurasian Soil Science 27: 5867.

[37] Matichenkov, V.V., Bocharnikova, E.A., Calvert, D.V., Snyder, G.H. (2000): Comparison study of soil silicon status in sandy soils of south Florida. - Soil Crop Sci. Florida Proc. 59: 132-137.

[38] Matichenkov, V.V., Bocharnikova, E.A. (2001): The Relationship between silicon and soil physical and chemical properties. - In: Datnoff, L. E., Snyder, G. H., Korndorfer, G. H. (eds). Silicon in Agriculture. Studies in Plant Science, v. 8. Elsevier, Amsterdam, 209-219.

[39] Munk, H. (1982): Zur bedentung silikatisher stoffe bei der oungung landwirtschaftlecker rulturpflanzen. - Landwirt Forsch 34: 264-277.

[40] Nazarov, A.G. (1976): Biogeochemical cycle of silica. - In: Kovda, V.A. (ed), Biogeochemical Cycles in the Environment. VII Plenum of SCOPE, Nayka, Moscow, 199-258.

[41] Olier, K. (1990): Weathering. - Nedra, Moscow.

[42] Snyder, G.H., Matichenkov, V.V., Datnoff, L.E. (2006): Silicon. - In: Barker, A.V. (Ed.) Handbook of Plant Nutrition, Massachusetts University, 551-568.

[43] Sommer, M., Kaczorek, D., Kuzuakov, Y, Breuer, J. (2006): Silicon pools and fluxes in soil and landscapes - a review. - J. Plant Nutr. Soil Sci. 169: 310-329.

[44] Thomas, G.W. (1996): Soil pH and soil acidity. In Methods of Soil Analysis. Part 3. Chemical Methods - SSSA Book Series no 5, Madison, WI, USA, 475-490.

[45] Urrutia, M.M., Beveridge, T.J. (1994): Formation of fine-grained silicate minerals and metal precipitates by a bacterial surface (Bacillus subtilis) and the implication in the global cycling of silicon. - Chem. Geol. 116: 216-280.

[46] Voronkov, M.G., Zelchan, G.I., Lykevic, A.Y. (1978): Silicon and Live. Zinatne, Riga. 
[47] Wattean, F., Villemin, G. (2001): Ultrastructural study of the biogeochemical cycle of silicon in the soil and litter of a temperate forest. - European J. Soil Sci. 52: 385-395.

[48] Wollast, R., McKenzie, F.T. (1983): The global cycle of silica. - In: Aston, S. R. (ed.): Silicon geochemistry and biochemistry. Academic Press, San Diego, 39-76.

[49] Yazinin, N.L. (1989): Genesis of residual solonetz. - Nayka, Alma-Ata.

[50] Yermolaev, A.M., Shirshova, L.T. (1994): Productivity and functioning of a Perennial sown meadow of various management type. - Pochvovedenie 12: 97-105.

[51] Yoshida, S. (1965): Chemical aspects of the role of silicon in physiology of the rice plant. - Bull. Natl. Agric. Sci. Series B. 15: 1-58. 